\title{
Parental Involvement in Secondary School Curriculum Implementation: The Case of East Wollega Zone, Ethiopia
}

\author{
Dereje Mengistu Tuli ${ }^{1}$ and Wudu Melese Tarekegne ${ }^{2 *}$ \\ ${ }^{1}$ Bule Hora College of Teacher Education, Bule Hora, Ethiopia \\ ${ }^{2}$ Department of Teacher Education and Curriculum Studies, Jimma University, \\ Ethiopia
}

\begin{abstract}
This study assesses the practices of parental involvement in curriculum implementation in East Wollega Zone in Ethiopia. To this end, a cross-sectional survey was designed. The data were collected from randomly selected teachers, students, Parent-Teacher Association (PTA) members, school principals, parents and supervisors through questionnaires and interview. Then, the quantitative data were analyzed and interpreted through frequency and mean score and the qualitative data were coded and narrated thematically. The findings indicated that the involvement of parents in general secondary schools curriculum implementation in East Wollega Zone was found to be low. However, efforts of the PTAs in having parents for planning and decision-making of curriculum implementation was high. The major challenges were inadequate school facility, inadequate training, parent's lack of awareness, lack of good governance, and the unwillingness of teachers. To increase parental involvement, general secondary schools, woreda and zone education offices may train stakeholders, allocate adequate budget and schools should design an income-generating mechanism to fulfil school facilities and making parents active in curriculum implementation.
\end{abstract}

Keywords: Parental Involvement; General Secondary Schools; Curriculum Implementation

* Corresponding Author.

wudumelese@gmail.com https://orcid.org/0000-0002-2501-0809
ISSN: 2091-0118 (Print) / 2091-2560 (Online)

(C) 2019 The Author(s). Journal homepages: ${ }^{1} \underline{\text { http: } / / w w w . k u s o e d . e d u . n p / j o u r n a l / i n d e x . p h p / j e ~}$ ${ }^{2}$ https://www.nepjol.info/index.php/JER/index 
Parental Involvement in Curriculum Implementation | 29

Introduction

Parental Involvement in Curriculum Implementation (PICI) has positive effects on students' academic achievement, social activities and behavioural development. According to Symeou (2003), parents at all grade levels are willing about their children's quality education and success and anticipate advice and help from schools on ways of helping their children for proper academic achievement and behavioural development. Thus, schools need to work with parents because parents are the first and the most important sources for students' pleasure, creativity, purpose and all-rounded education. Parents' follow-up and modelling continue to shape these young people from home to school and lay a strong foundation for their better lives (Kessler, 2000).

According to Emerson, Fear, Fox and Sanders (2012), parental involvement in curriculum implementation (CI) is associated with various indicators of student development and educational achievement. These include more regular school attendance, better social skills, improved behaviour, better adaptation to school, increased social behaviour, a greater sense of personal competence and efficacy for learning, greater engagement in school work, and a stronger belief in the importance of education. As parents participate in schools' curriculum implementation, students are motivated to learn and actively participate in their work, which leads to good academic achievement. Anyikwa and Obidike (2013) found that participation and support of parents at school and at home directly and positively impacts the educational performance of their children. As schools and parents work in cooperation, students understand that people who take care of them in both environments are at their homes and that they are coordinating time and resources to help them succeed. Parental involvement is a combination of commitment and active participation of the parents to the school and child (Gonzalez-Mena, 2011). The resulting corporations among students, parents and teachers develop effective communication from home to school and school to home, which has a positive impact on curriculum implementation.

Through active and ongoing communication, parents and teachers have to share information and resources regarding students' academic and behavioural concerns. Together, these efforts establish a basic foundation for both families and schools to help children succeed in school and their future. Anyikwa and Obidike (2013) stated that, for children to maximize their potentials from schooling, they need the full involvement of 
their parents. Schools, therefore, need to create a partnership with parents to achieve the intended goal of curriculum and recognize the primary role of the family in education.

The importance of parental involvement is also revealed by Morrison (2007) who describes that parents' involvement in children's learning positively affects the children's performance at school. Likewise, parental involvement in CI has significant and positive effects on students' grades, school attendance, and exposure to career opportunities (Holstead \& King, 2011). Among many benefits that students and schools enjoy are higher student achievement, better attendance, more positive attitudes and behaviour, improved teacher morale, higher ratings of teachers by parents and more support for families by schools. Therefore, to achieve these objectives, schools have the responsibility to work with the parents and the community in participating in curriculum implementation.

Parents' involvement can have positive impacts on the processes of CI with active and frequent contacts between parents and school administration to improve schools' teaching-learning process. Literature shows that effective schools have high levels of parental involvement in their curriculum implementation (Cheeks, 2012). Besides, greater parental involvement and support may lead to teachers having better and high relationships with parents and community, fewer behavioural problems, reduced workload and more positive attitude towards teaching and learning (Fan \& Williams, 2010). Therefore, the involvement of parents in CI is strongly related to improving students' academic achievement, social and psychological behaviour.

Scholars in the area such as Olibie (2014) conducted research in Nigeria to see male and female principals' perception of parental involvement and found out that there was no difference between genders. On the other hand, Ngigi (2014) conducted a study in Kenya to see the influence of parental involvement in primary school and found out that parental involvement was not as expected. However, this study focuses on general secondary school parental involvement in Ethiopia. In the case of Nepal also, scholars have underscored that parental engagement is necessary for children's learning as well as for better school governance (Dhakal, 2018; Munakarmi, 2015). Munakarmi also shares similar barriers in Nepal like weak mechanisms and structures for parental involvement in the classroom process, teacher's hegemony and feeling of superiority over parents, among others. 
Most of the existing researches in Ethiopia were focused on community involvement in primary schools rather than secondary schools (Melesew, 2005; Tadewos, 2014; Tadele, 2014). To the best knowledge of researchers, the practice of parental involvement in curriculum implementation in secondary schools has not been investigated so far. Therefore, this study was designed to assess the current practice of general secondary schools in promoting parental involvement in curriculum implementation. Accordingly, the following basic questions were raised:

1. To what extent general secondary schools involve parents' in curriculum implementation?

2. What are the major factors that affect parents' involvement in general secondary schools curriculum implementation?

\section{Research Method}

In this section, we discuss the detailed methods and techniques adopted to carry out his study. We begin with the broader research design to sampling and data collection instruments and then the validity and reliability of the tools. Finally, we conclude this section briefly shedding light into the data analysis process.

\section{Research Design}

To assess the practice of general secondary schools in promoting parental involvement in curriculum implementation cross-sectional survey design was used. The design was suitable for this study since it helped the researchers to describe the existing conditions of parental involvement in curriculum implementation (Creswell, 2011).

\section{Sample and Sampling Techniques}

The target population of this study was selected from parents, students, teachers, principals, supervisors and Parent-Teacher Association (PTA) members of East Wollega Zone in the central Oromia Region of Ethiopia. In this Zone, there are 17 woredas, 42 general secondary schools, 983 teachers and 37,068 students (as of September 2017). Generally, 8(47\%) woredas from17 woredas and 10 (55\%) from 18 general secondary schools were selected using simple random sampling. From the total population of the study, 379 sample populations were taken by using sample size determining published table (Cohen, Manion, \& Morrison, 2007). Therefore, from 14,152 parents, 178 parents were selected by snowball sampling technique. Since 
parents were out of schools, it was difficult to get unless their friends and students recommend them.

In addition, 103 student representatives were identified using the simple random sampling technique so as to give an equal chance of involvement. Students were also involved because, as the researchers assumed, they had enough information about the extent of parents' involvement in curriculum implementation. On the other hand, 60 teachers were selected using stratified random sampling to give an equal chance of involvement for teachers from different subject backgrounds.

Finally, $20(100 \%)$ principals, $8(100 \%)$ supervisors and $10(20 \%)$ from 50 PTAs were selected by purposive sampling technique owing to their experience and current position to prove appropriate information on the issue. Generally, a total of 178 parents, 103 students, 60 teachers, 20 principals, eight woreda supervisors and 10 PTAs were identified as sample participants.

\section{Instruments of Data Collection}

To collect data from respondents the following instruments were employed:

Questionnaire. The survey questionnaires (both closed-ended and open-ended) were prepared from relevant literature. First, it was written in the English language and translated into the local language (Afan Oromo) by language experts for parents and students to address language problems and to get reliable and valuable information. The questionnaires focused on secondary school role in encouraging parent's involvement in curriculum implementation activities and on factors that may affect parents' involvement. The questionnaire has 23 items in 6 dimensions on the areas of parental involvement on school curriculum implementation and it also includes 8 items on the factors part.

Interview. Semi-structured interview guidelines were prepared and used for five supervisors and seven PTA members. The interviews were conducted in the local language (Afan Oromo) and recorded, in order to minimize, potential loss of information.

\section{Validity and Reliability of the Instruments}

To maintain the validity of the instrument (both the questionnaire and interview guide) expert review was used and to check the reliability of the questionnaire pilot Journal of Education and Research, Vol. 9, No. 1, 2019 
Parental Involvement in Curriculum Implementation | 33

testing was conducted to check the reliability of the instruments. As a result, four items were deleted and few items were modified based on the comments given. The reliability coefficient of Alpha was calculated and it was found to be 0.930 which was highly reliable as indicated by (Cohen et al., 2007).

\section{Process of Data analysis}

The data collected with closed-ended questionnaires were analysed quantitatively using descriptive statistics such as mean and standard deviation. On the other hand, qualitative data collected via interview were analysed using narration to substantiate the quantitative results.

\section{Findings}

The results of this study focused on two issues: the level of parental involvement in curriculum implementation and factors affecting parental involvement. Parental involvement in curriculum implementation can be viewed in different dimensions. To assess the involvement of parents in parenting activity in curriculum implementation participants were requested to respond on different items and the result is presented in Table 1.

Table 1

The Extent of Involvement of Parents on Parenting Activity

\begin{tabular}{lllll}
\hline No. & Items & M & SD \\
\hline 1 & $\begin{array}{l}\text { School organizes workshops to explain new information to } \\
\text { parents on how to raise their children education. }\end{array}$ & 2.15 & .886 \\
2 & $\begin{array}{l}\text { School provides parents with information about their students' } \\
\text { growth in education and development. }\end{array}$ & 1.81 & 1.08 \\
3 & $\begin{array}{l}\text { School provides parents with information on how to provide their } \\
\text { children with the learning environment. }\end{array}$ & & \\
4 & $\begin{array}{l}\text { School asks families for information about children's goals, } \\
\text { strengths, and talents. }\end{array}$ & & .90 \\
5 & $\begin{array}{l}\text { School encourages parents to contact each other to exchange } \\
\text { experience. }\end{array}$ & 2.35 & .92 \\
\hline
\end{tabular}




\section{4 | D. M. Tuli \& W. M. Tarekegne}

As Table 1 illustrates, school efforts to involve parents were limited with aggregate mean of 2.37 which is considered as low. Furthermore, one of the interviewee PTA members stated that "Parents are coming to schools when their children create disciplinary problems like frequently being late or absent from school and make other disciplinary problems like a conflict with other students or teachers." The interview results also show that schools did not train parent and as a result, most of the parents do not have the awareness to involve in $\mathrm{CI}$ and exchange experience concerning the school activities.

The result revealed that the extent to which secondary school involve parents in parenting activities in organizing workshops, train parents, provides information about students growth and encourages parents to support their students learning in education in curriculum implementation in East Wollega zone was minimal.

The second area of parental involvement variable assessed in this study was the communication between schools and parents in curriculum implementation. To assess this variable different item were prepared and distributed to parents, students, teachers, and principals and the result is presented in Table 2.

\section{Table 2}

\section{The Extent of Communication Between the School and Parents}

\begin{tabular}{lllll}
\hline No. & Items & M & SD \\
\hline 1 & $\begin{array}{l}\text { School provides parents' with information about their } \\
\text { children's strength and weakness. }\end{array}$ & 2.57 & .920 \\
2 & $\begin{array}{l}\text { School encourages teachers to send students grade reports and } \\
\text { homework to parents. }\end{array}$ & 2.65 & 1.17 \\
3 & $\begin{array}{l}\text { School provides parents' with information about students } \\
\text { having academic or behaviour problems. }\end{array}$ & 3.05 & 1.49 \\
4 & $\begin{array}{l}\text { School conducts a formal conference with every parent at least } \\
\text { twice a year. }\end{array}$ & 3.44 & 1.03 \\
\hline
\end{tabular}

As shown in Table 2 above, the extent of communication between the school and parents in terms of exchange of information related to students' strength and weakness,

Journal of Education and Research, Vol. 9, No. 1, 2019 
grade report and student behaviour is considered as moderate since the average mean is found to be 2.48 .

Likewise, the interview result with one of the supervisors in school describes that "Schools conduct formal conferences with parents only twice a year at the beginning and the end of the academic year". General secondary school supervisors reported at least two general meetings a year, but in most schools, only a few parents attended the meetings. Schools didn't frequently communicate with parents due to lack of schools infrastructure and lack of awareness of the benefits of parental involvement in curriculum implementation.

The level of parental involvement in secondary school students learning at home was assessed and to assess this variable, different items were prepared and distributed to parents, students, teachers, and principals and the and the result is presented on Table 3.

\section{Table 3}

The Extent of Schools That Involve Parents in Learning at Home

\begin{tabular}{llll}
\hline No. & Items & M & SD \\
\hline 1 & $\begin{array}{l}\text { School provides parents with information that help them to } \\
\text { teach their children at home. }\end{array}$ & 2.38 & 1.036 \\
2 & $\begin{array}{l}\text { School encourages parents to support their children with } \\
\text { educational materials. }\end{array}$ & 2.29 & 1.136 \\
3 & $\begin{array}{l}\text { School provides information to parents on how to monitor and } \\
\text { discuss schoolwork at home. }\end{array}$ & 3.10 & 1.113 \\
4 & $\begin{array}{l}\text { School creates awareness parents' to support learning at home, } \\
\text { then completion of homework increase. }\end{array}$ & 1.88 & 1.068 \\
5 & $\begin{array}{l}\text { School aware parents to reduce students' workload and } \\
\text { students get enough time to learn at home. }\end{array}$ & 2.83 & 1.174 \\
\hline
\end{tabular}

The result in Table 3 above indicates that the extent of schools involve parents in learning at home in terms of providing information, materials, ways of monitoring progress and so on are found to be low with the average mean value of 2.38 . 
Correspondingly, the data collected from the interview with supervisors and PTAs indicated that schools did not regularly create awareness parents on the value learning at home. One of the PTA members said that "teachers simply give homework to students, but they didn't regularly aware parents to support and strength their children learning at home". From this result, the performance of schools in providing parents with information and encourage to be engaged in to assist their children in learning at was low.

Another way of involving parents in school curriculum implementation activity is through promoting volunteerism activity. To assess this issue, different items were prepared for participants and the result is presented in Table 4.

Table 4

The Extent of Parents' Involvement in Volunteerism

\begin{tabular}{llll}
\hline No. & Items & M & SD \\
\hline 1 & $\begin{array}{l}\text { School encourages parents to involve voluntary activities } \\
\text { like in school fund rising \& school buildings. }\end{array}$ & 3.01 & .980 \\
2 & $\begin{array}{l}\text { School asks parents about the activities that they can do } \\
\text { voluntarily. }\end{array}$ & 3.15 & .897 \\
3 & $\begin{array}{l}\text { School encourage parents to provide the school with } \\
\text { educational resources voluntarily for disadvantages }\end{array}$ & 2.61 & 1.136 \\
4 & $\begin{array}{l}\text { School give prizes and certificates to volunteered parents } \\
\text { who participate in the school activities }\end{array}$ & 3.29 & 1.058 \\
5 & $\begin{array}{l}\text { School involve parents in helping economically } \\
\text { disadvantaged and orphan }\end{array}$ & 2.22 & .942 \\
\hline
\end{tabular}

Table 4 above indicates that the extent of school involvement in volunteerism in the areas of fundraising for the school, provision of materials for the disadvantaged groups and so on and it is found out that the average mean score is 2.85 which are considered as moderate. From this result, it is possible to understand that school involving parents as volunteerism in the school or outside the school to support school programs and activities are not that much satisfactory.

Journal of Education and Research, Vol. 9, No. 1, 2019 
Another strategy to involve parents in curriculum implementation activity is the level of parental involvement in school decision making. And the result is presented in Table 5 below.

\section{Table 5}

The Extent of Effort That Schools Involve Parents in Decision-making

\begin{tabular}{llll}
\hline No. & Items & M & SD \\
\hline 1 & $\begin{array}{l}\text { School encourages parents to involve in planning \& decision } \\
\text { making in school activities. }\end{array}$ & 2.48 & 1.084 \\
2 & $\begin{array}{l}\text { School encourages parents to participate in school management. } \\
2\end{array}$ & 2.23 & 1.154 \\
& $\begin{array}{l}\text { School asks parents to be involved in solving problems that } \\
\text { encounter school. }\end{array}$ & 2.68 & 1.104 \\
4 & $\begin{array}{l}\text { School involves parents in revising school programs, contracts, } \\
\text { internal policies and regulations. }\end{array}$ & 2.48 & 1.076 \\
\hline
\end{tabular}

As it is indicated in Table 5, the degree of efforts that schools involve parents in decision making in school activities such as in planning, management, solving problems and revising school programs was found to be low with the average mean of 2.46. Similarly, the interview result shows similar finding, for instance, one of the PTA members in school 04 replied that "the participation level of students and parents was not practised by our school. Secondary school supervisor in school 06 revealed that most of the time general secondary schools did not involve parents in school management". From this result one can understand that the sample schools are not involving parents in the decision making process of the school.

Table 6 of this study offered the level of secondary school in collaborating with school community in curriculum implementation. To assess this issue different item were prepared and the summary of respondents view is presented in Table 6. 
38 | D. M. Tuli \& W. M. Tarekegne

Table 6

The Extent of Schools in Collaborate With Community in CI

\begin{tabular}{llll}
\hline No. & Items & M & SD \\
\hline 1 & $\begin{array}{l}\text { School provides parents with information about available } \\
\text { services in their community. }\end{array}$ & 2.28 & 1.21 \\
2 & $\begin{array}{l}\text { School organizes programs and activities for school with } \\
\text { community institutions for support. }\end{array}$ & 3.03 & .937 \\
3 & $\begin{array}{l}\text { School encourages all community institutions to participate in } \\
\text { school activities. }\end{array}$ & 2.55 & 1.03 \\
4 & $\begin{array}{l}\text { School encourages teachers and students to provide service to } \\
\text { their communities. }\end{array}$ & 2.08 & 1.14 \\
5 & $\begin{array}{l}\text { School has an educational agreement (contract) with parents to } \\
\text { work in collaboration for dual benefit. }\end{array}$ & 2.47 & 1.06 \\
\hline
\end{tabular}

Table 6 shows the extent of schools effort to collaborate with community in curriculum implementation like providing information about the available service and organizing programs and activities for school with community institutions for support and the result shows that schools attempt is considered as low with average mean value of 2.48. Correspondingly, the interview result with PTA members also shows that school community, PTAs and school did not have any agreement (contract) with parents to work in collaboration for the benefits of both school and community.

The second main issue of this study is related to factors affecting parental participation in curriculum implementation. There are many factors that can affect parental involvement in curriculum implementation. To identify these factors respondents were asked to rate the possible factors and the result is presented in Table 7.

Journal of Education and Research, Vol. 9, No. 1, 2019 
Table 7

The Factors Affecting Parental Involvement in CI

\begin{tabular}{llll}
\hline No. & Items & M & SD \\
\hline 1 & $\begin{array}{l}\text { Parents lack enough time to involve in curriculum } \\
\text { implementation. }\end{array}$ & 2.64 & 1.06 \\
2 & $\begin{array}{l}\text { Lack of school facilities like telephone, Face book, and email and } \\
\text { to communicate with parents about CI. }\end{array}$ & 4.02 & .963 \\
3 & $\begin{array}{l}\text { Parents lack of interest and commitment to involve in school } \\
\text { curriculum implementation. }\end{array}$ & 2.67 & 1.29 \\
4 & $\begin{array}{l}\text { Parents lack of skills and knowledge to involve in curriculum } \\
\text { implementation. }\end{array}$ & 1.98 & .945 \\
5 & $\begin{array}{l}\text { Parents lack of training from school to participate in their } \\
\text { children's education. }\end{array}$ & 3.85 & 1.17 \\
6 & $\begin{array}{l}\text { Teachers unwillingness, fear of failure and criticism from parents } \\
\text { to involve parents in CI }\end{array}$ & 3.58 & 1.88 \\
7 & $\begin{array}{l}\text { School lack of good governance and lack of well coming parents } \\
\text { to school to participate in CI. }\end{array}$ & 3.85 & .874 \\
8 & $\begin{array}{l}\text { School leaders' shortage of knowledge to run effectively parental } \\
\text { involvement in education. }\end{array}$ & 2.47 & 1.24 \\
\hline
\end{tabular}

Regarding the factors affecting parental involvement in CI (Table 7), the quantitative data shows that school facility related $(\mathrm{M}=4.02)$, stakeholders lack of training $(M=3.85)$, lack of good governance $(M=3.85)$, and teachers unwillingness and fear of criticism $(M=3.58)$ were the most common factors that affect parental involvement in secondary schools curriculum implementation.

As shown in Table 7 the strongest factor that affects parental involvement is lack of school facilities like telephone, face book, and email and to communicate with parents about curriculum implementation. The mean score 4.02 shows that lack of school facility is a major problem in CI. Likewise, the interview result also shows that, lack of 
school facility was great problems to communicate and exchange information between schools and parents. One of GSS supervisor interviewed in school 04 said that:

The involvement of school parents is very essential for the implementation of effective and quality teaching and learning in our school. However, due to the absence of school facilities, communication between school and parents is very weak. Our schools have facility problems like telephone and face book to establish effective communication between the school and parents.

The response from quantitative data and interview revealed that, lack of school facility is the highest problem in that hinder communication between schools and parents.

On the other hand, from the listed factors the least factor is parents' lack of skills and knowledge to involve in curriculum implementation. The weighted mean score is 1.98. Similarly, one of interviewed supervisor in school 02 said that:

Parents may not have skill and knowledge to involve in general secondary school curriculum implementation and what is expected of them is not the subject matter only. The school didn't invite parents to participate in CI like in planning, decision making, and program preparation. The school didn't make aware the parents about their roles and responsibility to participation in curriculum implementation.

From the respondents mean and interview result, the finding indicated that parent's lack of skill and knowledge in the involvement of school activities were not the hindering factor for involving parents in curriculum implementation.

Generally, the responses to open-ended question items at the end of the questionnaires regarding the major factors that might affect parents involvement in curriculum implementation, the majority of respondents were commonly stated factors such: insufficient training of teachers, principals, and supervisors on how to rise parental involvement in CI; lack of adequate school facility; lack of interest and commitment of school principals and teachers to involve parents in CI; parents lack of awareness on their roles and responsibilities; and inadequate follow up from school management and concerned body. Besides, lack of school agreements and charters for accountability and responsibility; lack of fixed meeting or conference time; lack of 
Parental Involvement in Curriculum Implementation | 41

good governance and weak communication system between school and parents were the identified factors

\section{Discussion}

Parents have a vital role in their children's education when they actively participate in curriculum implementation. Therefore, schools should recognize different types of parental involvement strategies to engage them in their children's education. They also need to deal with any obstacles that could prevent parents from being involved in curriculum implementation.

Generally speaking, parents have a vital role in their children's education when actively participated in curriculum implementation. Therefore, schools should recognize different types of parental involvement to engage parents in their children's education at secondary schools and other levels. They also need to deal with any obstacles that could prevent parents from being involved in curriculum implementation.

Based on the results of this study from the six dimensions of parental involvement it is found out that parental involvement is moderate on dimensions related to communication between schools and parents, learning at home, and voluntarism. However, researchers in the area (including Eccles \& Harold, 1996; Fan \& Williams, 2010) strongly recommend that the school should have more contact with parents and that parent should have more communication to facilitate curriculum implementation in the school. Since greater parental involvement and support may lead to teachers having better and high relationships with parents and community, fewer behavioural problems, reduced workload and more positive attitude towards teaching and learning. Similarly, scholars such as Petr (2003) suggested that the family is the most important and most enduring resource in a child's life and family-school partnerships produce impressive results for children and teachers.

On the other hand, parental involvement in curriculum implementation is found to be low in areas of parenting activity, decision making and collaboration. However, the available literature in the area shows that school helping parents with parenting and child-rearing skills, understanding child development and supporting home conditions that encourage child achievement. For instance, Kotirde and Yonus (2014) found that, participating parents in schools for assisting families with parenting and child-rearing 
skills, family support, understanding child and adolescent development and creating home conditions to support learning at every stage and grade level.

Likewise, parental involvement in school governance and decision making contributed to the effectiveness of teachers in improving student learning and performance (Boaduo, Milondzo, \& Adjei, 2009). Literature shows that the decentralization of school management can make decision-making more democratic and lead to improved efficiency and effectiveness (Abebe, 2012). It is known that, as parents participate actively in school decision making, can foster improvements in school performance and can contribute more effectively to community development.

Many factors can affect parental involvement in curriculum implementation. According to the response of the participants, the serious problem identified is the lack of school facilities like telephone, Facebook, and email which can affect the communication between parents about curriculum implementation. In addition, the response from the interview revealed that the school facility is the highest problem in that hinder communication between schools and parents. Substantiating the above idea the finding confirmed with Hanke (2006), lack of parental involvement was due to lack of helpful information to parents due to school facility. Ministry of Education (2010) also stated that school infrastructures and school facilities in secondary schools are classrooms, library, laboratory, water, latrines, clinics, internet, electricity and plasma television.

Another main challenge identified is teachers' unwillingness; fear of failure and fear of criticism from parents affect parents' involvement in education. This means that most of the teachers are unhappy to contact with parents because they fear comments and suggestions forwarded from student parents regarding teaching learning process. This finding is consistent with the finding of Aggrawal (1996) that indicates teachers prevent parental involvement due to their unwillingness to face hostile parent, fear of failure and fear of criticism.

\section{Conclusion}

Parental involvement in the school curriculum implementation efforts has a paramount importance, and thus secondary schools are expected to involve parents in the school activities. However, the findings of this study show that school efforts to mobilize and involve parents in the curriculum implementation process on six

Journal of Education and Research, Vol. 9, No. 1, 2019 
dimensions of involvement (parenting activity, communication, learning at home, volunteerism, decision making and collaboration with the community) are found to be low. This shows that curriculum implementation activities in the secondary schools are not supported by parents and as a result, it hampers the expected outcome of student learning.

The major challenges that affect parents' involvement in CI are lack of adequate school facility, lack of awareness of parents on their roles and responsibilities, inadequate follow-up from school management, lack of sufficient training, and lack of good governance. These imply that secondary school principals are not active enough in mobilizing and encouraging the parents and community in solving the school problems. In order to address these pertinent issues, the region education bureau together with other relevant stakeholders can organize training, seminars or conferences for parents, principals, supervisors and teachers on the importance and how to involve parents in curriculum implementation. Likewise, for effective parental involvement in curriculum implementation, the school principals and teachers can make efforts for reaching and involving parents in positive outlook and have readiness to design and implement strategies that will result in improved parental involvement in curriculum implementation. Finally, secondary school teachers, principals, and supervisors may undertake more action research studies to find better ways to increase parents' involvement in curriculum implementation.

\section{References}

Abebe, W. (2012). School management and decision-making in Ethiopian government schools: Evidence from the Young Lives qualitative school survey (Working Paper 86). Oxford, England: Young Lives.

Aggrawal, J. C. (1996). Theory and principles of education: Philosophical and sociological bases of education (10th ed.) New Delhi, India: Vikas.

Anyikwa, N., \& Obidike, N. (2013). Mothers' constructions of their roles in the literacy education of their children. Africa Development, 37(3), 57-67.

Boaduo, N. A.-P., Milondzo, K., \& Adjei, A. (2009). Parent-community involvement in school governance and its effects on teacher effectiveness and improvement of learner performance: A study of selected primary and secondary schools in Botswana. Educational Research and Review, 4(3), 096-105. 
44 | D. M. Tuli \& W. M. Tarekegne

Cheeks, M. (2012). The impact of learning centers as a parent-involvement aid to improve student success (Unpublished doctoral thesis). Abraham S. Fischler School of Education, Nova Southeastern University Florida, Florida, FL.

Cohen, L., Manion, L., \& Morrison, K. (2007). Research methods in education (6th ed.). New York, NY: Routledge Falmer.

Creswell J, W. (2011). Planning, conducting, and evaluating quantitative and qualitative research (4th ed.). Boston, MA: Pearson.

Dhakal, R. K. (2018). An ethnographic study on inclusive school governance in Nepal. Paper presented at the 2nd International Conference on Transformative Education Research and Sustainable Development (TERSD), 6-8 October 2018, Kathmandu University, Dhulikhel, Nepal.

Eccles, J. S., \& Harold, R. D. (1996). Family involvement in children's and adolescents' schooling. In A. Booth \& J. F. Dunn (Eds.), Family-school links: How do they affect educational outcomes? (pp. 3-34). Mahwah, NJ: Erlbaum.

Emerson, L., Fear. J., Fox, S., \& Sanders, E. (2012). Parental engagement in learning and schooling: Lessons from research. Canberra, Australia: Australian Research Alliance for Children and Youth (ARACY) for the Family-School and Community Partnerships Bureau.

Fan, W., \& Williams, C. M. (2010). Effects of parental involvement on students' academic self-efficacy, engagement and intrinsic motivation. Educational Psychology, 30(1), 53-74.

Gonzalez-Mena, J. (2011). Foundations of early childhood education: Teaching children in a diverse setting. New York, NY: McGraw-Hill.

Hanke, W. (2006). How to get parents involved with school activities. Retrieved from http $/ / \mathrm{www}$.indiana.edu/ safeschl/ParentIn volvement.pdf

Holstead, J., \& King, M. H. (2011). High-quality 21st century community learning centers: Academic achievement among frequent participants and non-participants. Journal of Education for Students Placed at Risk, 16(4), 255-274.

Kessler, R. (2000). The soul of education. Alexandria, VA: ASCD.

Kotirde, I. Y., \& Yonus, J. M. (2014). Parent participation and school child education quality in secondary school In Nigeria. International Journal of Education and Research, 2(6), 511-516.

Journal of Education and Research, Vol. 9, No. 1, 2019 
Melesew, T. (2005). An assessment of community participation in the management primary school of wag Himra zone (Unpublished master's dissertation). Addis Ababa University, Ethiopia.

Ministry of Education. (2010). Education sector development program IV (ESDP IV). Addis Ababa, Ethiopia: Author.

Morrison, G. S. (2007). Early childhood education today. Upper Saddle River, NJ: Pearson Merrill Prentice Hall.

Munakarmi, R. (2015). Parental involvement in school: A case study of Kavre (Unpublished MPhil dissertation). Kathmandu University, Dhulikhel, Nepal.

Ngigi, K. F. (2014). Influnce of parental involvement in the implementation of curriculum in public elementary schools in Ndeiya Zone, Kiambu County, Kenya (Unpublished master's thesis). University of Nairobi, Kenya.

Olibie, E. I. (2014). Parental involvement in curriculum implementation as perceived by Nigeria secondary school principals. Journal of Education and Learning, 3(1), p40.

Petr, C. G. (2003). Building family-school partnerships to improve student outcomes: A primer for educators. Lanham, MD: Scarecrow Press.

Symeou, L. (2003). Fostering children's learning: An investigation of the role of teacher-parentt briefing. Paper presented at the British Educational Research Association Annual Conference Research Student Symposium, Heriot-Watt University, Edinburgh, 11 September 2003. Retrieved from http //www.leeds.ac.uk/educol/documents/00003196.htm

Tadele, B. (2014). An assessment of community participation in education: The case of Lideta sub city (Unpublished master's dissertation). Addis Ababa University, Ethiopia.

Tadewos, H. (2014). Factors influencing community participation in the implementation of primary school curriculum in primary schools of Axum town, Tigray Region (Unpublished master's dissertation). Addis Ababa University, Ethiopia.

\section{To cite this article:}

Tuli, D. M., \& Tarekegne, W. M. (2019). Parental involvement in secondary school curriculum implementation: The case of East Wollega Zone, Ethiopia. Journal of Education and Research, 9(1), 28-45. https://doi.org/10.3126/jer.v9i1.28821 